\title{
Multimodality imaging and management of an asymptomatic saccular LAD aneurysm
}

\author{
Wael Abuzeid, ${ }^{1}$ Navneet Singh, ${ }^{2}$ Gorka Bastarrika, ${ }^{2}$ Shaheeda Ahmed ${ }^{2}$
}

'Sunnybrook Health Sciences Centre, Toronto, Ontario, Canada

${ }^{2}$ University of Toronto, Toronto, Ontario, Canada

\section{Correspondence to} Dr Wael Abuzeid, wael.abuzeid@mail.utoronto.ca

Accepted 27 January 2016
CrossMark

To cite: Abuzeid $W$, Singh N, Bastarrika G, et al. BMJ Case Rep Published online: [please include Day Month Year] doi:10.1136/ bcr-2016-214450

\section{DESCRIPTION}

An incidental saccular left anterior descending (LAD) coronary artery aneurysm was detected in a 72-year-old patient undergoing non-gated chest CT evaluation for the development of a seroma postmastectomy for invasive lobular carcinoma. The LAD aneurysm (arrowhead) was confirmed on gated CT imaging with three-dimensional reconstructions (figure 1A, B) and detected on sagittal oblique reformats (figure $1 \mathrm{C}$ ).

The incidence of coronary aneurysms ranges from $1.5 \%$ to $5 \%$ of angiographic studies. ${ }^{1}$ Multivessel coronary aneurysms have been described and are more common in Kawasaki disease. ${ }^{1}$ Atherosclerosis is the most common aetiology of this condition in the developed world. ${ }^{2}$ Guidelines for management of an asymptomatic population are not available. Medical therapy, if possible, should be directed to the specific cause of the coronary aneurysm.

Covered stenting is the primary therapeutic consideration in uncomplicated symptomatic aneurysms. Surgical treatment options (eg, total aneurysm resection, coronary artery bypass graft, proximal and distal end ligation) are reserved for complications such as fistula formation and compression of adjacent structures.
In our case, given the absence of symptoms and low risk of rupture, we elected to follow the patient at 6 months, then annually with CT to ensure stability of the aneurysm. Features associated with favourable prognosis include location, size $<8 \mathrm{~mm}$, absence of mural thrombus and no history of distal coronary aneurysm. ${ }^{3}$ Medical management for our patient, who had hypertension, included the use of acetylsalicylic acid, statin and a $\beta$-blocker. The patient remained asymptomatic with no change in aneurysm size by computed tomography angiography (CTA) 2 years since its detection.

\section{Learning points}

Atherosclerosis is the most common aetiology of coronary aneurysms in the developed world.

- CT imaging with three-dimensional reconstruction can yield reliable images for follow-up of coronary aneurysms.

- Treatment options include observation versus percutaneous intervention (eg, covered stent) versus surgical repair.

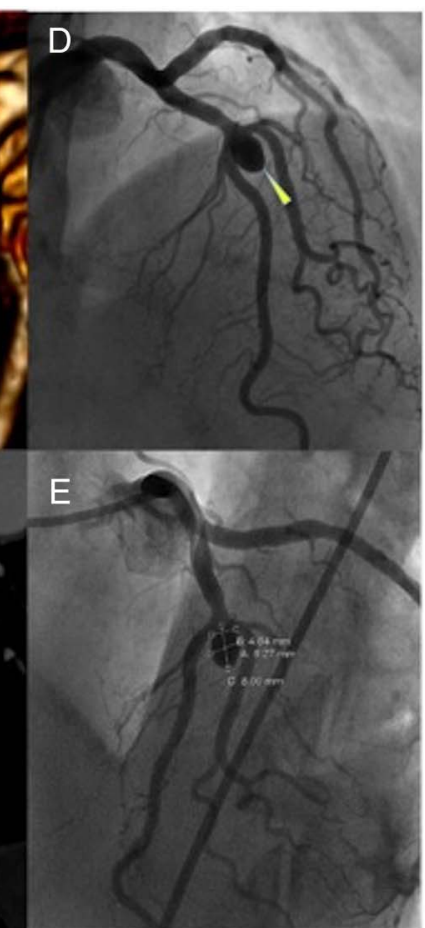

Figure 1 Left anterior descending (LAD) aneurysm (yellow arrowhead) depicted on gated CT imaging three-dimensional reconstructions $(A$ and $B$ ) and a sagittal oblique reformat $(C)$. Coronary angiography of the LAD saccular aneurysm shown in the cranial right anterior oblique view (D) and cranial left anterior oblique view (E) measuring $8 \times 6 \mathrm{~mm}$. 
Contributors WA and NS participated in the initial write-up and preparation of the images. GB and SA were involved in editing the manuscript and preparing it for submission.

Competing interests None declared.

Patient consent Obtained.

Provenance and peer review Not commissioned; externally peer reviewed.

\section{REFERENCES}

1 Syed M, Lesch M. Coronary artery aneurysm: a review. Prog Cardiovasc Dis 1997;40:77-84.

2 Cohen P, O'Gara PT. Coronary artery aneurysms: a review of the natural history, pathophysiology, and management. Cardiol Rev 2008;16:301-4.

3 Angelini P, Monge J. Newer concepts regarding adults with coronary artery aneurysms: are they all Kawasaki? Does it make a difference? Circulation 2012;125:3076-8.

Copyright 2016 BMJ Publishing Group. All rights reserved. For permission to reuse any of this content visit http://group.bmj.com/group/rights-licensing/permissions.

BMJ Case Report Fellows may re-use this article for personal use and teaching without any further permission.

Become a Fellow of BMJ Case Reports today and you can:

- Submit as many cases as you like

- Enjoy fast sympathetic peer review and rapid publication of accepted articles

- Access all the published articles

- Re-use any of the published material for personal use and teaching without further permission

For information on Institutional Fellowships contact consortiasales@bmjgroup.com

Visit casereports.bmj.com for more articles like this and to become a Fellow 